ІНВЕСТИЦІЙНО-КРЕДИТНЕ ЗАБЕЗПЕЧЕННЯ АГРОПРОМИСЛОВОГО КОМПЛЕКСУ УКРАЇНИ

\title{
INVESTMENT AND CREDIT SUPPORT OF THE AGRO-INDUSTRIAL COMPLEX OF UKRAINE
}

\begin{abstract}
Стаття присвячена дослідженню сучасного стану інвестиційно-кредитного забезпечення агропромислового комплексу України. Визначено пріоритетні напрямки самофрінансування агропромислового комплексу. Зазначено, що Україна інтегрована у світове господарство, не знаходиться поза світовими процесами і залишається привабливою для інвестицій. Запропоновано підвищити дієздатність механізмів забезпечення сприятливого інвестиційного клімату збереження конкурентоспроможності вітчизняної економіки; для покращення інвестиційного забезпечення в АПК сконцентрувати зусилля формування агропідприємствами власних ресурсів; розробити механізм розвитку інноваційно-інвестиційної діяльності сільськогосподарських товаровиробників із залучанням державної підтримки, покращити кредитне забезпечення за рахунок урізноманітнення кредитних інструментів. Обгрунтовано впровадження кластеризації АПК України із механізмом інноваційності для фрормування власних ресурсів.

Ключові слова: інвестиційно-кредитне забезпечення, агропромисловий комплекс, фрінансове забезпечення, державна підтримка, кредитні ресурси, інвестиції, кластеризація, інноваційність
\end{abstract}

Статья посвящена исследованию современного состояния инвестиционно-кре- дитного обеспечения агропромышленного комплекса Украины. Определены приоритетные направления самофинансирования агропромышленного комплекса. Отмечено, что Украина интегрирована в мировое хозяйство не находится вне мировых процессов и остается привлекательной для инвестиций. Предложено повысить дееспособность механизмов обеспечения благоприятного инвестиционного климата сохранения конкурентоспособности отечественной экономики; для улучшения инвестиционного обеспечения в АПК скончентрировать усилия формирования агропредприятиями собственных ресурсов; разработать механизм развития инновационно-инвестиционной деятельности сельскохозяйственных товаропроизводителей с вовлечения государственной поддержки, улучшить кредитное обеспечение за счет разнообразия кредитных инструментов. Обосновано внедрение кластеризации АПК Украины с механизмом инновационности для фоормирования собственных ресурсов.

Ключевые слова: инвестиционно-кредитное обеспечение, агропромышленный комплекс, финансовое обеспечение, государственная поддержка, кредитные ресурсы, инвестиции, кластеризация, инновационHOCmb.

Black Sea Research Institute of Economy and Innovation

The article is devoted to the study of the current state of investment and credit support of the agro-industrial complex of Ukraine. According to the results of the analysis, the priority areas of self-financing of the agro-industrial complex are identified, namely - the establishment and transformation of the agroindustrial complex of Ukraine into a cross-cutting agro-industrial agglomeration using a cluster approach. The tools of the innovative cluster approach will allow to balance the interests of producers and the state, smooth out the negative effects of market competition and conditions, diversify the risks of socioeconomic development of agriculture, maximize the potential of self-government and self-development of enterprises and their associations. economic security. It is noted that Ukraine is integrated into the world economy and remains attractive for investment. The originality and practical significance of the study lies in substantiating the introduction of clustering of the agro-industrial complex of Ukraine with the mechanism of innovation as a mega cluster system of end-to-end targeted cooperation and integration of business entities vertically and horizontally to form own resources. The results, in contrast to the known ones, are to take into account the latest trends and features of agro-industrial development, taking into account international experience, as well as state goals and objectives for the development of national agro-industrial complex and its integration into the international agri-food space. Clustering of agro-industrial complex is a megacluster system of end-to-end targeted cooperation and integration of business entities vertically (production, processing, marketing) and horizontally (territorial and regional location), which are interested in dynamic development of production and marketing infrastructure and increase of total income based on rational production, technical, technological and natural resources, as well as for the formation of own resources. It is proposed to improve the investment climate to increase the efficiency of mechanisms to ensure a favorable investment climate to maintain and increase the competitiveness of the domestic economy and to concentrate efforts to form agricultural enterprises' own resources to improve their efficiency, develop a mechanism for innovation and investment collateral through a variety of credit instruments.

Key words: investment and credit provision, agro-industrial complex, financial support, state support, credit resources, investments, clustering, innovation.

Постановка проблеми. Останніми роками українська економіка тримається здебільшого за рахунок аграрного сектору. Малий і середній бізнес сільського господарства потребують коштів для фрінансування своєї поточної діяльності, для впровадження інновацій та новітніх технологій, для розбудови необхідної інсрраструктури. «3 цією метою використовуються власні та залучаються нові фрінансові ресурси (інвестування та кредитування). Але аграрний бізнес потрапив у пастку обмеженого доступу до ресурсів за наявності значної кількості фрінансових інструментів на ринку України» [1].
Аналіз останніх досліджень і публікацій. Дослідженню інвестиційної діяльності банківського інвестування вивчали вітчизняні й зарубіжні вченіекономісти, зокрема, значний внесок зробили: П. Денисенко, А. Пересада, Т. Майорова, О. Вовчак, А. Мороз, М. Туріанська та інші. Основні теоретичні і методологічні, а також практичні питання, пов'язані з фрінансовим забезпеченням діяльності агарних підприємств, їх особливостями в умовах ринкових відносин, висвітлені у наукових працях: І. Абрамова, В. Андрійчука, І. Вініченка, О. Гудзя, П. Стецюка, С. Ілляшенка. В цих працях узагаль- 
нено міжнародний досвід і тенденції фрінансування підприємств сільського господарства. Теоретичні та методичні питання кредитування підприємств АПК досліджували у своїх працях: В. Борисова, М. Дем'яненко, Ю. Лупенко, О. Непочатенко та інші. Виходячи з того, що ресурси аграрної галузі динамічні, тому потребують подальшого дослідження та аналітичної оцінки з метою визначення пріоритетних напрямків його фрінансування.

Постановка завдання. Мета статті - проаналізувати сучасний стан інвестиційно-кредитного забезпечення агропромислового комплексу України.

Виклад основного матеріалу дослідження. «Оцінка інвестиційної привабливості галузі сільського господарства не обмежуються тільки показниками надійності та доходності. Інвестиційна привабливість АПК характеризуються сукупністю об'єктивних і суб'єктивних чинників. Нажаль, на сьогодні, у міжнародних рейтингах Україна поки що не потрапляє до переліку країн з привабливим інвестиційним кліматом, що гальмує інвестиційні процеси» [2].

За висновками експертів «...найбільш вагомими причинами інвестиційного спаду були несприятлива для сільгоспвиробників аграрна політика, скорочення бюджетної підтримки аграріїв, звуження можливостей залучення інвестицій і неприйнятні для потенційних вкладників капіталу ризики інвестування» [1]. Додамо ще і те, що перезавантаження влади та зниження зацікавленості банків в кредитуванні стримували діяльність інвесторів. Також стагнація процесів залучення інвестицій відбулася і із-за високої ставки кредитів, низького рівня довіри до українських агрокомпаній на фрондових ринках, відсутності власних внутрішніх інвесторів тощо.

Обсяги вкладень у сільському господарстві, мисливстві та наданні пов'язаних із ними послуг зменшилися. Найбільше зниження обсягів інвестицій в агропромисловій сорері зафріксовано в сфері лісового господарства та лісозаготівлі. Обсяги капітальних інвестицій в АПК у загальному обсязі освоєних капітальних інвестицій наведено (табл. 1).

В АПК накопичуються й поглиблюються численні проблеми. Основні 3 них - нерозвиненість виробничої інвестиційної та інноваційної інфрраструктури, надмірний знос основних засобів і відсутність умов їх відтворення, недостатня ліквідність інвестицій, невирішеність проблеми іпотеки, брак фрінансування заходів з розвитку шляхової мережі на селі тощо.

«Аграрний бізнес - це одна з найбільш сприятливих областей для інвестування грошей. Банки охоче видають кредити для сільського господарства, так як в Україні максимально сприятливі умови для вирощування різних рослинних культур, а також в нашій країні добре розвинені аграрні традиції» [4]. «На сьогоднішній день сільськогосподарські кредити мають відносно високі процентні ставки. Але, як державні, так і приватні фрінансові компанії пропонують позичальникам найрізноманітніші кредитні програми. Кредитні програми для агросектору наведено (табл. 2).

«Під час кредитування банками можна виділити загальні стримуючі фрактори, актуальні для всіх напрямів кредитування: недостатня система захисту прав кредиторів та інвесторів; висока вартість кредитів; високі відсоткові ставки; облікова ставка НБУ, яка визначає прибутковість інструмен-

Обсяги капітальних інвестицій в АПК у загальному обсязі освоєних капітальних інвестицій (січень-вересень відповідного року), \%

\begin{tabular}{|l|c|c|c|c|c|}
\hline \multicolumn{1}{|c|}{ Показники } & $\mathbf{2 0 1 4}$ & $\mathbf{2 0 1 5}$ & $\mathbf{2 0 1 6}$ & $\mathbf{2 0 1 7}$ & $\mathbf{2 0 1 8}$ \\
\hline Сільське, лісове та рибне господарство & 8,2 & 10,7 & 14,6 & 15,8 & 13,4 \\
\hline Виробництво харчових продуктів, напоїв і тютюнових виробів & 6,7 & 4,9 & 5,7 & 4,9 & 4,4 \\
\hline
\end{tabular}

Джерело: [3]

Таблиця 2

Кредитні програми, що пропонують банки агровиробникам

\begin{tabular}{|l|l|}
\hline \multicolumn{1}{|c|}{ Банк } & \multicolumn{1}{c|}{ Вид кредитного продукту } \\
\hline АБ «Укргазбанк» & $\begin{array}{l}\text { «Нове обладнання від Республіки Білорусь», «Сільськогосподарська техніка } \\
\text { від Республіки Білорусь», «Транспортні засоби від Республіки Білорусь» }\end{array}$ \\
\hline «Агропросперіс Банк» & «АП Експрес», «АП Інвест», «АП Урожай» \\
\hline АТ «ОТП Банк» & «Агрофрабрика» \\
\hline ПАТ «Мегабанк» & «Агромікрокредит» \\
\hline «Сredit Agricole» & Комплексна програма для агробізнесу від «Sуngenta», СК «АХА Страхування» \\
\hline «равекс-Банк» & «Кредити не фінансування посівної кампанії», «Кредити під зібраний врожай (товарні)» \\
\hline ПАТ «ПриватБанк» & Кредитна лінія «Агросезон», «АгроКУБ», «Гарантовані платежі» \\
\hline
\end{tabular}

Джерело: узагальнено автором за даними [1; 4] 
тів управління ліквідністю, наприклад депозитних сертифрікатів НБУ; низька якість фрінансового планування, обліку та звітності; відсутність достовірної статистики землекористування; відсутність ліквідної «твердої» застави А відтак, банківські кредити неспроможні повною мірою забезпечити потреби сільськогосподарських підприємств у кредитних ресурсах. І як висновок - банківські кредити видаються на коротко- та середньотермінові періоди; регулювання кредитного забезпечення $є$ малоефективним, державна підтримка - недостатньою» [1].

«На сьогодні зростає потреба галузі і підприємств АПК в необхідних капітальних ресурсах для переходу їх на новий рівень розвитку зі стійкою конкурентоспроможністю і платоспроможністю. Основним завданням $€$ поліпшення фрінансовоекономічного стану АПК, досягнення регулярного зростання обсягу інвестиційної складової» [5].

За цих умов подолання економічного суперечностей і надання необхідного поштовху для розвитку агропромислового виробництва можливе не тільки на основі нівелювання існуючої економічної диференціації, а й за рахунок інших організаційних, економічних та управлінських підходів, тобто, за рахунок заснування та перетворення АПК України в наскрізну агропромислову агломерацію 3 використанням кластерного підходу.

Інструменти інноваційного кластерного підходу дозволять отримати баланс між інтересами виробників та держави, згладити негативні прояви ринкової конкуренції та кон'юнктури, урізноманітнити ризики соціально-економічного розвитку АПК, максимально використати потенціал самоуправління та саморозвитку підприємств та їх об'єднань за допомогою заходів їх централізованого регулювання та економічного забезпечення.

Використовуючи кластерний підхід, аграрна політика може набути всебічного збалансованого характеру і отримати можливість включити механізми інноваційності. Головна мета кластерної політики полягає у забезпеченні сталого розвитку і підвищенні конкурентоспроможності економіки через формування та посилення інтеграційних відносини між суб'єктами господарювання різних галузей та видів діяльності, більш ефективно використовувати науковий, інноваційний, технічний, технологічний, промисловий, фінансовий, економічний, управлінський та кадровий потенціал.

Зауважимо, що кластерна політика, із механізмом інноваційності стосовно АПК, має певну поетапність, де кожен етап має свою специфріку співпраці та інтеграції. Така послідовність кроків або алгоритм представлений (рис. 1).

Процедура та механізм створення наскрізної кластерної структури із механізмом інноваційності в АПК включає послідовні кроки - від появи ідеї до орієнтації отримання якісної продукції за критеріями конкурентоспроможності та задоволе- ності споживачів. Представлений алгоритм має наукову новизну, який полягає у розробці певної технології для створення та встановлення ефективного функціонування кластерних інтеграційних формувань в АПК України із механізмом інноваційності, а дотримання умов кожного етапу дає можливість створювати кластерні фрормування в логічній послідовності, усуваючи можливі втрати залучених ресурсів.

Основні наслідки фрормування кластерної системи є: інвестиційна привабливість (державні, приватні, іноземні); сталий розвиток технологічної бази та ресурсного потенціалу, впровадження новітніх технологій, використання наукових досягнень в інноваційній сорері, освоєння конкурентних видів виробництва; оптимізація різних ресурсів, включаючи зайнятість у всіх кластерних підрозділах; цілеспрямоване збільшення виробництва та максимальна реалізація експортного потенціалу; стабільне зростання валового внутрішнього продукту і продуктивності праці, використовуючи найбільш ефрективні системи мотивації праці; концентрація найбільш кваліфрікованого персоналу, стрімкий розвиток компетенції менеджерів та спеціалістів, зайнятих в різних секторах кластеру; самофінансування.

Можливий склад показників для забезпечення об'єктивної оцінки стану кластеризації АПК: обсяг та види кластерної продукції, в тому числі інноваційної; частка доданої вартості від виробництва інноваційної продукції в загальній сумі; рівень рентабельності інвестицій для всього кластера продукція; кількість створених робочих місць в інноваційній частині виробництва; рівень продуктивності праці в інноваційній частині виробництва; темпи зростання доходу від продажу інноваційної продукції порівняно з динамікою загального доходу кластера; розмір заробітної плати на одного працівника в інноваційній частині виробництва у порівнянні із загальною зарплатою в кластері та загальною зарплатою в АПК; кластерна частка в перерахунку на основні виробничо-фрінансові показники у всьому комплексі АПК інфраструктури; розміри та географрія експорту інноваційної конкурентоспроможної продукції.

Але, сьогодні, існує низка обмежень та суперечностей, які перешкоджають впровадженню кластеризації у сорері АПК, а саме: відсутність спеціального законодавства, щодо пріоритетного розвитку кластерних структур та інноваційно-інтеграційних фрормувань; відсутність довгострокової позитивної практики щодо пріоритетного розвитку кластерних структур та інноваційно-інтеграційних фрормувань; слабкий інноваційний потенціал агропромислового виробництва та відсутність зацікавленості суб'єктів господарювання у співпраці, інтеграції та створенні кластерних структур; розрив між вітчизняним агропромисловим виробництвом та інноваційними процесами у світовому сіль- 


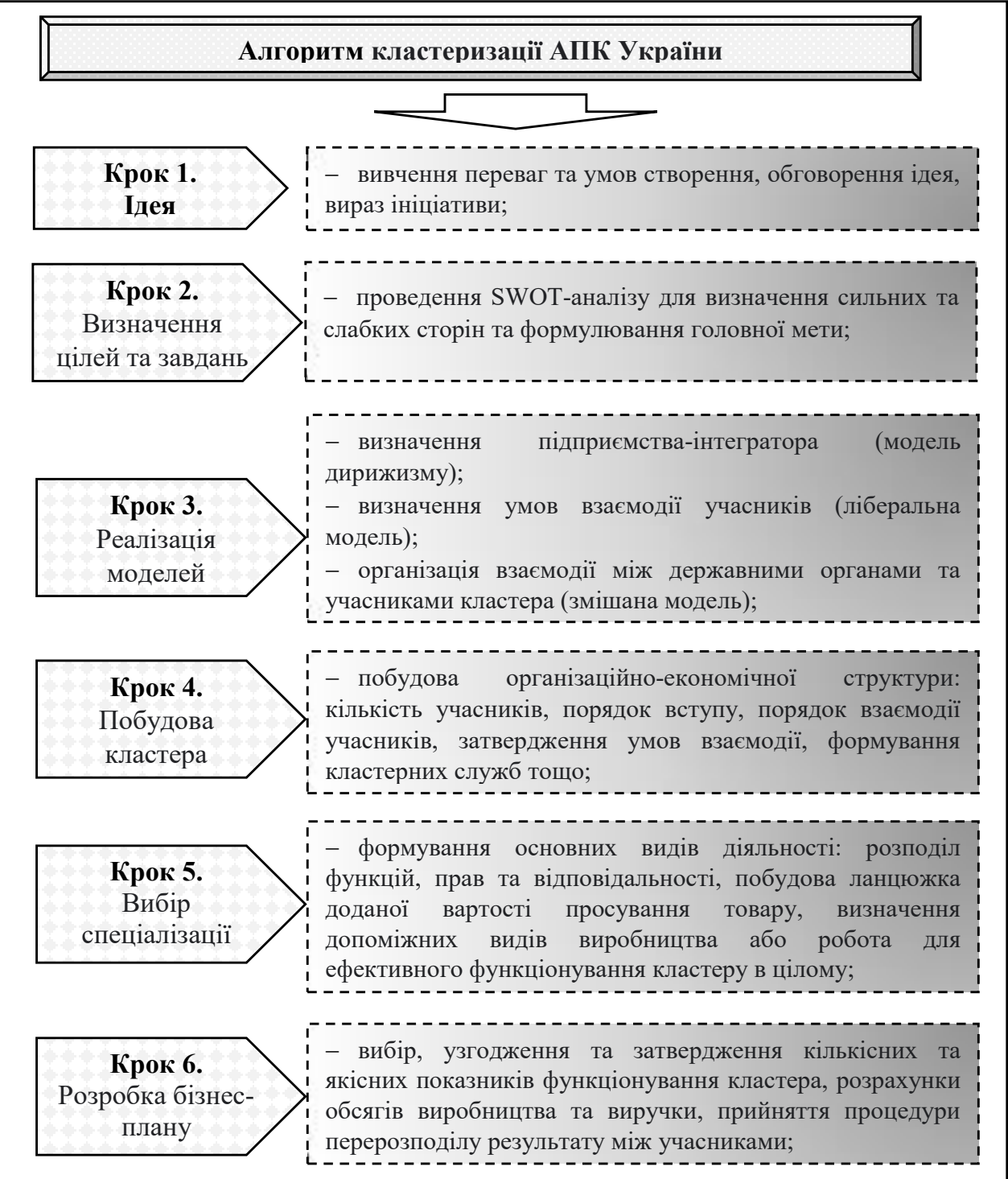

\begin{tabular}{|c|l} 
Крок 7. \\
Стимулювання \\
та мотивація
\end{tabular}$\backslash \begin{aligned} & \text { організації та мотивації праці для ефективного } \\
& \text { функціонування кластерної організації; }\end{aligned}$
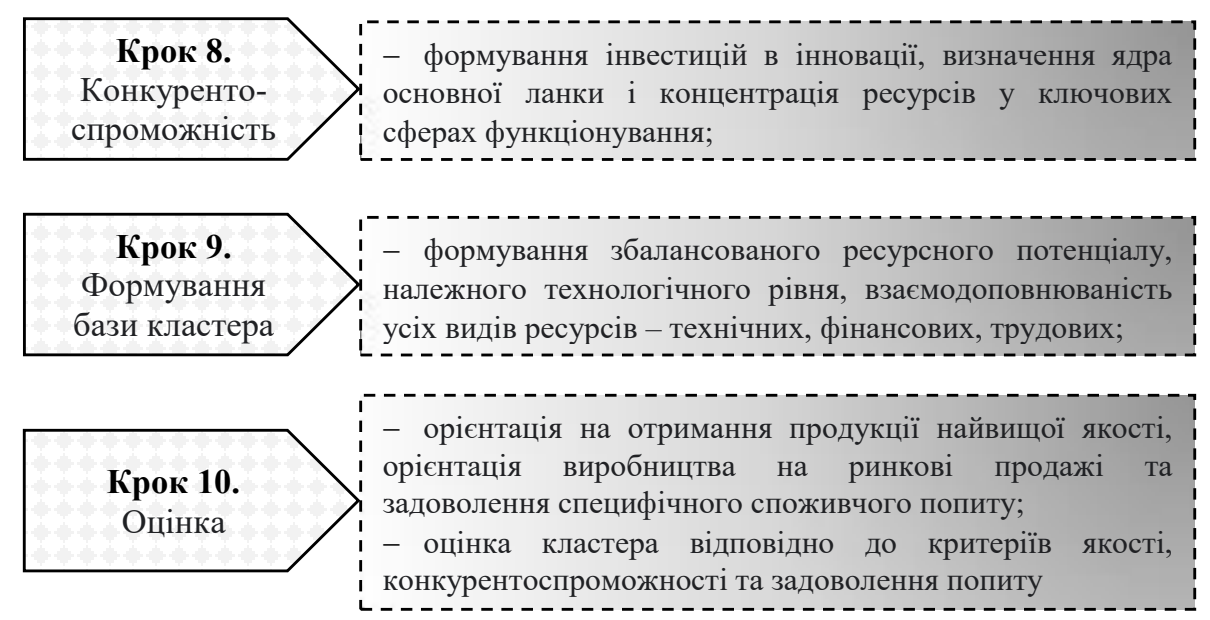

Рис. 1. Модель та алгоритм стратегії кластеризації АПК України із механізмом інноваційності

Джерело: розроблено автором 
ському господарстві; ізоляція існуючих агропромислових підприємств, що прагнуть створити, в своїх межах, необхідну інфрраструктуру і, які задоволені у виробництві продукції з низькою доданою вартістю та низьким рівнем інновацій; недостатня пропаганда інноваційно активних підприємств та об'єднань; низький рівень довіри до наукових та інноваційних методів управління; інституційний дисбаланс в агроекономічній системі; відсутність процесів навчання та перепідготовки кадрів 3 питань кластеризації в освітній системі.

Однак, існують позитивні фрактори-стимулятори. Такими стимулюючими фракторами є: наявний досвід у формуванні та розвитку різних фрорм співпраці та інтеграції, створенні на їх основі різних територіально-виробничих комплексів та кооперативно-інтеграційних структур (трести, спілки, асоціації тощо); існування теорії і практика створення харчових компаній, які демонструють переваги співпраці та інтеграції в АПК (молочні компанії, м'ясні асоціації, племінні агропромислові підприємства тощо); ефрективність - більш великі агропромислові підприємства та об'єднання мають більш сучасні технології виробництва та є прикладами подальшої співпраці для інтеграції (есректу масштабу); можливість збільшення виробництва та збуту на експорт, розширення географрії експортних продажів; постійне вдосконалення якості готової продукції за різноманітним споживчим попитом.

Існує і багато інших фракторів, які свідчать на користь кластеризації, співпраці та інтеграції. Наприклад, Україна досягне повної продовольчої безпеки через внутрішнє виробництво. В країні буде діяти збалансована спеціалізація, добре розвинена система розподілу сільськогосподарської продукції, існуюча необхідна інфраструктура - виробництво, маркетинг, переробка, закупівля тощо. Держава отримає додаткові доходи до бюджету та зменшить обсяги фрінансування АПК за рахунок самофрінансування суб'єктів кластеру, отримає можливість розвитку інноваційної сорери, зменшить рівень безробіття, посилить харчову безпеку в країні, зміцнить позиції на міжнародних ринках тощо.

Висновки 3 проведеного дослідження. Україна інтегрована у світове господарство і залишається привабливою для інвестицій, але, порушення на зовнішніх ринках стабільності та відповідного балансу має свій відголос, тому для покращення інвестиційного клімату необхідно підвищити дієздатність механізмів забезпечення сприятливого інвестиційного клімату для збереження та підвищення конкурентоспроможності вітчизняної економіки. Непослідовна та недосконала інвестиційна політика держави в якій переважав і переважає принцип залишкового виділення коштів 3 бюджету в агропромисловий комплекс, розпочала процес спаду інвестиційного забезпе- чення ще у 2019 році. Для покращення інвестиційного забезпечення в АПК, необхідно: по-перше, сконцентрувати зусилля для фрормування агропідприємствами власних ресурсів для підвищення ефективності їх діяльності; по-друге, розробити механізм розвитку інноваційно-інвестиційної діяльності сільськогосподарських товаровиробників із залучанням державної підтримки; по-третє, покращити кредитне забезпечення за рахунок урізноманітнення кредитних інструментів.

Для створення кластерів та забезпечення їх необхідної конкурентоспроможності, необхідно розробити та впровадити низку критеріїв та показників. Звичайно, в кожному випадку, необхідно враховувати специфіку діяльності, рівень спеціалізації та виробничий напрям, економічну й організаційну та фрінансову підтримку з боку держави.

\section{БІБЛІОГРАФІЧНИЙ СПИСОК:}

1. Артем'єва О. О. Банківське кредитування АПК: сучасний стан та перспективи розвитку. Науковий вісник Ужгородського національного університету. Серія: Міжнародні економічні відносини та світове господарство. 2018. Вип. 21. Ч. 1. С. 13-18.

2. Шпортько Г. Ю., Козенкова Н. П., Козенкова В. Д. Оцінка інвестиційної привабливості промислового підприємства. Ефективна економіка. 2014. № 11. URL: http://www.economy.nayka.com.ua/ ?op=1\&z=3550 (дата звернення: 10.11.2018).

3. Офріційний сайт Державного комітету статистики України. URL: http://www.ukrstat.gov.ua (дата звернення: 02.01.2019).

4. Особливості кредитування сільського господарства. URL: https://www.ccloan.ua/new/kredituvannjasilskogo-gospodarstva/ (дата звернення: 10.11.2018).

5. Сердобинцев Д. В., Сорокина Л. В., Бекетова Е. С. Интеграция предприятий молочнопродуктового подкомплекса на основе кластерного подхода. Аграр. наука. 2012. № 8. С. 2-4.

\section{REFERENCES:}

1. Artemjeva O. A. (2018) Banking lending applications: current state and prospects of development. Scientific Bulletin of Uzhhorod National University. Series: International Economic Relations and the World Economy. vol. 21, no. 1, pp. 13-18.

2. Shportko G. Yu., Kozenkova N.P., Kozenkova V.D. (2014) Assessment of investment attractiveness of an industrial enterprise. Efficient economy, no. 11. Retrieved from: http://www.economy.nayka.com. ua/?op=1\&z=3550 (accessed: 10.11.2018).

3. State Statistics Committee of Ukraine. Retrieved from: http://www.ukrstat.gov.ua (accessed: 02.01.2019).

4. Features of agricultural lending. Retrieved from: https://www.ccloan.ua/new/kredituvannja-silskogogospodarstva/ (accessed: 10.11.2018).

5. Serdobincev D. V., Sorokina L. V., Beketova E. S. (2012) Integracija predprijatij molochnoproduktovogo podkompleksa na osnove klasternogo podhoda. Agrar. Nauka, no. 8, pp. 2-4. 
Zasoba Serhii

Graduate Student

Black Sea Research Institute of Economy and Innovation

\section{INVESTMENT AND CREDIT SUPPORT OF THE AGRO-INDUSTRIAL COMPLEX OF UKRAINE}

The article is devoted to the study of the current state of investment and credit support of the agro-industrial complex of Ukraine. According to the results of the analysis, the priority areas of self-financing of the agro-industrial complex are identified, namely - the establishment and transformation of the agro-industrial complex of Ukraine into a cross-cutting agro-industrial agglomeration using a cluster approach. The tools of the innovative cluster approach will allow to balance the interests of producers and the state, smooth out the negative effects of market competition and conditions, diversify the risks of socio-economic development of agriculture, maximize the potential of self-government and self-development of enterprises and their associations. economic security. It is noted that Ukraine is integrated into the world economy and remains attractive for investment. The originality and practical significance of the study lies in substantiating the introduction of clustering of the agro-industrial complex of Ukraine with the mechanism of innovation as a mega cluster system of end-to-end targeted cooperation and integration of business entities vertically and horizontally to form own resources. The results, in contrast to the known ones, are to take into account the latest trends and features of agro-industrial development, taking into account international experience, as well as state goals and objectives for the development of national agro-industrial complex and its integration into the international agri-food space. Clustering of agro-industrial complex is a megacluster system of end-to-end targeted cooperation and integration of business entities vertically (production, processing, marketing) and horizontally (territorial and regional location), which are interested in dynamic development of production and marketing infrastructure and increase of total income based on rational production, technical, technological and natural resources, as well as for the formation of own resources. It is proposed to improve the investment climate to increase the efficiency of mechanisms to ensure a favorable investment climate to maintain and increase the competitiveness of the domestic economy and to concentrate efforts to form agricultural enterprises' own resources to improve their efficiency, develop a mechanism for innovation and investment collateral through a variety of credit instruments. 